\title{
Ranking of Journals in Library and Information Science: A Comparison of Perceptual and Citation-based Measures
}

\section{Mary T. Kim}

\begin{abstract}
A citation analysis of core library and information science journals was conducted to identify factors associated with subjective rankings of a journal's value in promotion and tenure decisions. Prestige rankings from a 1982 survey of ARL directors and library school deans were correlated with nine citation measures: total citation count, impact factor, immediacy index, references per paper, Price's Index, self-citation rate, popularity factor, citation factor, and consumption factor, with and without controlling for journal orientation, age, circulation, and index coverage. Results indicate that deans and directors may differ in their weighting of scholarliness and timeliness when rating journal value, especially when the practitioner-research orientation of the journal is considered.
\end{abstract}

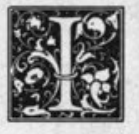

n a 1982 survey of ARL directors and deans of library schools, David F. Kohl and Charles H. Davis obtained subjective ratings of thirty-one core library science journals in terms of their importance for promotion and tenure decisions. ${ }^{1}$ Using a five-point scale, directors and deans rated those journals with which they were familiar. Kohl and Davis then used these ratings to rank order the journal set into a perceived hierarchy of journal prestige. Critics of subjective journal rankings have argued that such rankings are "artificially precise indicators ${ }^{\prime 2}$ which may, in fact, not be significantly different from each other. ${ }^{3}$ Whether these rankings reflect an actual hierarchy of journal importance or whether they merely group journals into clusters of high and low prestige, members of the academic community do use them to identify top library and information science (LIS) journals. For example, in a statistical profile of College \& Research Libraries (CERL) on its fiftieth anniversary, Paul Metz described CERL as "one of the most widely respected journals in librarianship," noting that ARL directors and library school deans ranked it first and third, respectively, in terms of "its value for tenure and promotion decisions at their institutions." ${ }^{\prime 4}$ " self-fulfilling prophecy" occurs because, once publicized, these subjective rankings influence assessment of the best outlet for a journal article and the subsequent weight assigned to it in personnel decisions.

This author recalls a comment made at a discussion group on negotiating the tenure process held at an Association for Library and Information Science Education conference: "If it's not published in one of the top ten or twelve journals listed in the Kohl and Davis study, it doesn't count as much." If these journal rankings do, in fact, establish norms for the field, then 
Kohl and Davis' recommendation for additional research appears valid: namely, to take a "close look at the ranking of the journals to determine whether there are objective factors that correlate with journal prestige," such factors to be derived by citation analysis. ${ }^{6}$ This paper presents the results of the recommended citation analysis. Its purposes are to determine whether journal characteristics do differentiate between varying levels of perceived LIS journal prestige and to determine if citation-based measures yield similar rankings within the LIS journal network. The goal is not to challenge the ranking assigned to specific journals, but to understand more fully the factors contributing to these rankings.

\section{CITATION MEASURES}

Actual journal use, citation-based measures, and subjective judgments are the three indicators typically used to rank journals. Each perhaps taps a different aspect of journal "worth," and each is potentially distorted by common and unique sources of bias. R. Todorov and $\mathrm{W}$. Glanzel recently reviewed the more familiar journal citation measures used for journal ranking. A brief summary seems appropriate here. ${ }^{7}$ The raw data for computing citation measures are the bibliographic references appearing in substantive papers (i.e., source items) within a set of journals for a specified period of time. These references are interpreted as links between journals, journals giving references to and receiving citations from each other. Once a citation analyst decides which subset of journals and source items is appropriate for a given purpose, citation measures may be computed.

Total citations are tallies of the citations received by a given journal. Because these are biased in favor of larger journals with more source items, citation analysts have developed size-independent measures. The impact factor is computed as the total citations given to a journal for a specified time period divided by the number of source items published in that journal during that same time pe- riod. Because the previous two years is the typical time period, the impact factor also measures how quickly authors cite work appearing in a journal. Although corrected for journal size, the impact factor may still be biased in favor of older journals or journals with review articles. The immediacy index is computed as the total citations received from journals published in the same year divided by the number of source items available for citation in a journal that year. Factors such as journal circulation or publication delay may influence both the impact factor and immediacy index. These three indicators measure journal usefulness as an aid in knowledge production. Whether cited positively or negatively, journal contents have stimulated or supported some written endeavor. ${ }^{8}$

Derek J. de Solla Price developed two alternative measures for scholarliness and the scientific "hardness" of a journal. He believed high references per paper, the total number of references in a journal divided by the number of source items in a journal, reflected the cumulative effect of knowledge building in a scholarly area. Price defined the normal range for scholarship as ten to twentytwo references per paper, with a typical value being fifteen. Price's Index, the proportion of the total references in a journal to work published within the last five years, indicates the rapidity of development of a field and the degree to which journal references were made to the research front of the field. Price stated that higher index values indicated harder, scientific journals, while lower index values indicated journals dependent on the archival literature, not the research front. ${ }^{9}$ More recently, Sydney J. Pierce has suggested that Price's Index reflects not only the degree to which older research has been integrated into the knowledge base of a field, but also the level of consensus as to what constitutes the knowledge base for a field-the lower the index, the lower the consensus. ${ }^{10}$ Obviously, citation norms of a field and the editorial policies of a journal may influence Price's Index and references per paper. 
The final set of citation measures to be considered deals with popularity and the position of the journal in the information flow of a field. V. I. Yanovsky proposed ratios of citations to citations and journals to journals. He believed these to be better indices of interaction among sets of journals than other sizeindependent ratios such as the impact factor. ${ }^{11}$ The citation factor is the ratio of the citations received by a journal in a year to the references given by a journal in the same year. This is the inverse of the input/output ratio described by Louis V. Xhignesse and Charles E. Osgood and may be interpreted as the degree to which a journal feeds or stores information in the journal network. ${ }^{12}$ Journals with higher citation factors would feed information; journals with lower citation factors, store information. The popularity factor, the ratio of the number of journals citing a journal to the number of journals referenced by a journal, has been described as a measure more appropriate for identifying less research-oriented journals. ${ }^{13}$ The consumption factor, the product of the citation factor and the popularity factor of a given journal, appears to tap dimensions other than journal quality. Journals with higher consumption factors tend to be older, with a higher circulation rate, and a lower number of references per paper. ${ }^{14}$ The self-citation rate, the proportion of citations received by a journal which stem from the journal itself, also indicates the degree of interaction with the journal network. Highly specialized journals in discipline subfields or more practitioner-oriented journals with low referencing patterns would probably have higher self-citation rates.

Because each of the citation indicators reviewed appears to measure a different dimension of journal significance, they have all been used as ranking measures in this study. Discipline versions, similar to Graeme Hirst's discipline impact factor, have been computed for each of the indices involving total citation counts. ${ }^{15}$

\section{CORRELATES OF SUBJECTIVE JOURNAL RANKINGS}

Investigators ranking journals by one method often correlate these rankings with those obtained by another method, the goal being a better understanding of what their rankings actually represent. In a detailed review of journal ranking methods, Alan Singleton discussed problems with each approach and examined the relationship between methods. ${ }^{16}$ Overall, he noted low correlations between subjective judgments of prestige and various citation rankings in the area of physics. In contrast, Bruce C. Bennion and Sunee Karshamroon found a moderately high multiple correlation $(R=.74)$ between perceived usefulness of physics journals and a set of four citation indicators (total source items, impact factor, immediacy index, and citation factor). This correlation increased when journal circulation rate was considered $(\mathrm{R}=.85) .{ }^{17}$ Other researchers have reported rank-order correlations between perceived quality and impact factor for journals in the social sciences $(\mathrm{rho}=.45)$, and subfields of psychology $($ rho $=.39-.56)$, sociology $($ rho $=.63)$, and economics (rho $=.87$ ). ${ }^{18}$ John C. Smart found a low correlation between impact factor and perceived quality for 678 educational journals ( $r h o=.21$ ). $\mathrm{Re}$ analysis of this relationship within journal types (i.e., core and allied) resulted in higher correlations ( $\mathrm{rho}=.33$ and rho $=.52){ }^{19}$

Collectively, these studies demonstrate the need to study these ranking relationships within disciplines and to consider carefully the type of journals included in the discipline network. Analysts of professional knowledge structures support this latter recommendation, arguing that the journal literature of a profession consists of two different components-research-oriented and practitioner-oriented journals which vary in their referencing patterns and behaviors. $^{20}$

Investigators have also reported that some citation indicators have higher correlations with perceived quality or use- 
fulness than others. Michael D. Gordon noted that total citations correlated more highly with perceived prestige (rho = .61) than did the size-independent impact factor (rho $=.45$ ) or immediacy in$\operatorname{dex}(\mathrm{rho}=.30)$. His study suggests that prestige may be more closely related to the size of a journal and dependency on it over time than the speed with which a journal is cited by later works. ${ }^{21}$ Smart and C. F. Elton reported a low rankorder correlation between consumption factor and subjective judgments of quality for psychology journals (rho $=.13$ ). They concluded that the consumption factor ranked journal quality by some dimension other than the "communication of original research" normally measured by perceived quality rankings. ${ }^{22}$ These studies suggest that citation measures do measure different facets of journal significance. Exploring the relationship between LIS prestige rankings and the set of citation measures would expand the current understanding of subjective rankings of LIS journals.

This review identifies the following sources of bias for citation-based and subjective journal rankings: discipline, journal orientation, age, size, and circulation. S. M. Dhawan, S. K. Phull, and S. P. Jain would add to this list coverage by indexing services. ${ }^{23}$ Where possible, these extraneous factors have been considered in the selection of journals or in the relationships analyzed.

\section{HYPOTHESES}

The author posed the following directional research hypotheses to test common conceptions about prestige rankings:

Hypothesis Set 1: LIS journals with higher prestige rankings will typically (a) be older journals, (b) have higher circulation rates, (c) be covered by more indexing services, and (d) be more research oriented.

Because of the inconsistencies in research relating different types of ranking methods, nondirectional research hypotheses guided tests for the following relationships:

Hypothesis Set 2: LIS journal prestige rankings will be significantly correlated with journal rankings by (a) total discipline citations, (b) discipline impact factor, (c) discipline immediacy index, (d) references per paper, (e) Price's Index, (f) discipline citation factor, (g) discipline popularity factor, (h) discipline consumption factor, and (i) discipline self-citation rate.

To determine whether the hypothesized relationships between prestige and citation measures might be due to common factors such as journal age or circulation, the following set of nondirectional hypotheses was tested:

Hypothesis Set 3: LIS journal prestige rankings will be significantly correlated with journal rankings by (a) total discipline citations, (b) discipline impact factor, (c) discipline immediacy index, (d) references per paper, (e) Price's Index, (f) discipline citation factor, (g) discipline popularity factor, (h) discipline consumption factor, and (i) discipline self-citation rate, after controlling for journal age, journal circulation, index coverage, and journal orientation.

\section{PROCEDURE}

Because only citations from journals in the LIS discipline were to be considered when computing discipline citation measures, the first step in the study was to determine the appropriate journal set. As Patrick Doreian points out, the omission of key journals may distort citation measures more than the inclusion of less significant journals which contribute little to or receive little from the journal network. ${ }^{24}$ Consequently, this study expanded the original thirty-one journal set used by Kohl and Davis. English language journals were added if they were listed as both citing and cited LIS source journals in the Journal Citation Report (JCR) of the Social Science Citation Index, were major ALA journals (i.e., not newsletters), and were consistently referenced by journals in the original thirty-one journal set. This iterative process of addition and deletion resulted in the fifty-two journal network listed in appendix $\mathrm{A} .{ }^{25}$

Because Kohl and Davis conducted 
their survey in fall 1982, this study used citation data from the 1983 and 1984 SSCI Journal Citation Reports to correspond to the time frame of development, submission, and final publication for papers written in fall 1982. Using citation data from two years also reduced journal idiosyncracies of subject focus for a given year. Sixteen network journals not covered by JCR required hand tallies of their 1983-84 references. Ten of these sixteen were in the original thirty-one journal network. Three of the original network titles were excluded because of low citations/references (Harvard Library Bulletin and International Journal of Law Libraries) or cessation of publication in 1983 (Library of Congress Quarterly Journal).

Discipline citation measures were computed for each of the twenty-eight remaining Kohl and Davis journals. Appendix $B$ contains definitions for these measures. The 1983 Ulrich's International
Periodicals Directory provided information on journal age, circulation, and coverage by indexing services. Using Price's minimum of ten references per paper as an indication of scholarly orientation, the author divided the journals into popular, practical journals such as Library Journal, Wilson Library Bulletin, and School Library Journal, and more research-oriented journals such as $\mathrm{Li}$ brary Quarterly, College \& Research Libraries, Journal of the American Society for Information Science, and Library Trends. If a journal employed referees in its review process, it was classified as a more scholarly journal. ${ }^{26}$

\section{RESULTS AND DISCUSSION}

The twenty-eight LIS journals were rank ordered by each of the discipline citation measures as well as the three "demographic" journal characteristics (age, circulation, and index coverage). Table 1 compares the top dozen journals identi-

TABLE 1

TOP TWELVE JOURNALS IDENTIFIED BY EACH RANKING METHOD*

\begin{tabular}{|c|c|c|c|c|c|c|c|c|c|c|c|c|c|c|c|}
\hline \multirow[b]{2}{*}{ Journal } & \multirow{2}{*}{\multicolumn{2}{|c|}{$\begin{array}{l}\text { Prestige } \\
\text { ARL LS }\end{array}$}} & \multirow[b]{2}{*}{ DTC } & \multirow[b]{2}{*}{ DIF } & \multirow[b]{2}{*}{ DII } & \multicolumn{7}{|c|}{$\begin{array}{l}\text { Ranking Methods } \\
\text { Citation-based Methods }\end{array}$} & \multirow{2}{*}{\multicolumn{2}{|c|}{ Demographics }} & \multirow[b]{2}{*}{$(\mathrm{R} / \mathrm{P})$} \\
\hline & & & & & & $\begin{array}{c}\text { Citati } \\
\text { RP }\end{array}$ & $\begin{array}{l}\text { n-ba: } \\
\text { Pl }\end{array}$ & $\begin{array}{l}\text { ed Met } \\
\text { DCF }\end{array}$ & $\begin{array}{l}\text { Iods } \\
\text { DPF }\end{array}$ & DSCR & DCSF & AGE & & & \\
\hline$C R L$ & $\mathrm{X}$ & $x$ & $\mathrm{X}$ & $\mathrm{X}$ & $X$ & $x$ & & $\mathrm{X}$ & & $\mathrm{X}$ & $\mathrm{X}$ & $\mathrm{X}$ & $\mathrm{X}$ & $\mathrm{X}$ & $\mathrm{R}$ \\
\hline$L Q$ & $\mathrm{x}$ & $x$ & $\mathrm{x}$ & $\mathrm{x}$ & & $\mathrm{x}$ & & $\mathrm{x}$ & $\mathrm{x}$ & $\mathrm{X}$ & $\mathrm{X}$ & $x$ & & $\mathrm{x}$ & $\ddot{R}$ \\
\hline$\widehat{I A L}$ & $\mathrm{X}$ & $\underset{v}{x}$ & $X$ & $X$ & $x$ & & $\mathrm{X}$ & & $\mathrm{X}$ & $x$ & & & $\underset{x}{X}$ & $\mathrm{x}$ & R \\
\hline LRTS & $x_{x}^{x}$ & $\underset{x}{x}$ & $\underset{x}{X}$ & $\mathrm{X}$ & $x$ & $\underset{x}{x}$ & $\mathrm{X}$ & & & $\begin{array}{l}x \\
x\end{array}$ & & $\underset{x}{x}$ & $\mathrm{X}$ & X & $\begin{array}{l}\mathrm{R} \\
\mathrm{R}\end{array}$ \\
\hline $\begin{array}{l}\text { LibTr } \\
\text { ITEL }\end{array}$ & $\begin{array}{l}x \\
x\end{array}$ & $\stackrel{x}{x}$ & $X$ & & & X & $x$ & & & X & & X & $\mathrm{X}$ & $\begin{array}{l}x \\
x\end{array}$ & $\begin{array}{l}\mathrm{K} \\
\mathrm{R}\end{array}$ \\
\hline JASIS & $\hat{x}$ & $\mathrm{x}$ & $x$ & $X$ & $x$ & $\mathrm{x}$ & & $x$ & $x$ & & $x$ & $x$ & $x$ & $x$ & R \\
\hline & $\mathrm{x}$ & & $\mathrm{x}$ & $\mathrm{x}$ & $x$ & & $\mathrm{x}$ & $\mathrm{x}$ & $\mathrm{x}$ & & $\mathrm{x}$ & $x$ & $x$ & $\mathrm{x}$ & $\mathrm{P}$ \\
\hline $\begin{array}{l}\text { AmLib } \\
R Q\end{array}$ & $\begin{array}{l}x \\
x\end{array}$ & & $\begin{array}{l}x \\
x\end{array}$ & $\begin{array}{l}x \\
x\end{array}$ & $x$ & $\mathrm{X}$ & $\begin{array}{l}x \\
x\end{array}$ & $\begin{array}{l}\hat{x} \\
x\end{array}$ & $\begin{array}{l}\hat{x} \\
x\end{array}$ & $\begin{array}{l}x \\
x\end{array}$ & $\begin{array}{l}\hat{x} \\
x\end{array}$ & $\hat{x}$ & $\hat{x}$ & $\begin{array}{l}\hat{x} \\
x\end{array}$ & $\begin{array}{l}\mathrm{P} \\
\mathrm{R}\end{array}$ \\
\hline SpLib & $\hat{x}$ & $\mathrm{x}$ & $\hat{x}$ & $\hat{x}$ & $\mathrm{x}$ & & $\hat{x}$ & & $\hat{x}$ & & & $x$ & $\hat{x}$ & $\hat{x}$ & $\mathrm{R}$ \\
\hline WLB & X & & X & & $x$ & & $x$ & $x$ & $x$ & $X$ & $X$ & $\mathrm{X}$ & & $x$ & $P$ \\
\hline $\begin{array}{l}\text { LISR } \\
\text { ILH }\end{array}$ & & $\begin{array}{l}x \\
x\end{array}$ & & $x$ & & $\begin{array}{l}x \\
x\end{array}$ & & & & X & & & & & $\begin{array}{l}\mathrm{R} \\
\mathrm{R}\end{array}$ \\
\hline JEL & & 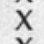 & & & & & & $X$ & $X$ & $X$ & $X$ & & & & $\mathrm{R}$ \\
\hline $\begin{array}{l}\text { DLQ } \\
\text { Online }\end{array}$ & & $\mathrm{X}$ & $x$ & $x$ & $\begin{array}{l}x \\
x\end{array}$ & $\mathrm{X}$ & $x$ & $\begin{array}{l}x \\
x\end{array}$ & $\begin{array}{l}x \\
x\end{array}$ & $\mathrm{X}$ & $x$ & & & & $\begin{array}{l}R \\
P\end{array}$ \\
\hline$S L M Q$ & & & & & & $x$ & & & & & $\hat{x}$ & $x$ & $\mathrm{X}$ & & $\mathrm{R}$ \\
\hline SLJ & & & & & & & & $\begin{array}{l}x \\
x\end{array}$ & X & $X$ & $\begin{array}{l}x \\
x\end{array}$ & $\mathrm{X}$ & $\underset{x}{x}$ & $\mathrm{X}$ & $P$ \\
\hline LawLJ & & & & & & X & & & & & & $\mathrm{X}$ & & & $P$ \\
\hline IPEMgt & & & & & & $\mathrm{X}$ & & & & & & & & $x$ & $R$ \\
\hline $\begin{array}{l}\text { MicroK } \\
\text { RSR }\end{array}$ & & & & X & 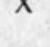 & & $\mathrm{X}$ & & & & & & & & $\mathrm{P}$ \\
\hline CollMgt & & & & & & & & & & & & & & & $\mathrm{R}$ \\
\hline $\begin{array}{l}\text { PubLib } \\
\text { ILibRev }\end{array}$ & & & & & & & $X$ & & & & & & & & $\begin{array}{l}\mathrm{P} \\
\mathrm{R}\end{array}$ \\
\hline LibAcq & & & & & & & $x$ & & & & & & & & $\mathrm{P}$ \\
\hline
\end{tabular}

*With the exception of DCSF, ranking is in descending order. See appendix A for journal abbreviations. 
fied by these rankings to the top dozen identified by each of the perceived prestige rankings. Table 1 also lists the journal orientation for each title ( $R$ or $P)$. The clustering of $x^{\prime}$ s at the top of table 1 suggests that the ranking methods collectively do identify a set of top journals. For example, at least eight of the eleven ranking methods ranked College \& Research Libraries, Library Quarterly, Library Resources \& Technical Services, Journal of the American Society for Information Science, Library Journal, American Libraries, $R Q$, Special Libraries, and Wilson Library Bulletin among the top dozen journals.

\section{Hypothesis Set 1}

To test the first set of hypotheses, Spearman rank order correlations were computed between the first three journal demographics and the two prestige rankings, first for the total journal set $(\mathrm{N}$ $=28$ ) and then separately for the research $(\mathrm{N}=17)$ and practitioner $(\mathrm{N}=$ 11) subsets. ${ }^{27}$ An alpha level of .05 was used to test the first two sets of hypotheses. Because journal orientation is a dichotomous variable, prestige rankings were first reduced to a dichotomous level using a median split. Phi coefficients were then computed to analyze the prestige-orientation relationship. As table 2 indicates, the deans' prestige rankings were significantly correlated with journal orientation ( $\mathrm{phi}=.56$ ), confirming the research hypothesis that the more research-oriented the journal, the higher its prestige ranking. The broader mix of research-practitioner journals in the directors' top journals probably accounts for the lack of a significant relationship between journal orientation and director prestige rankings.

As table 2 further indicates, the data failed to support the hypothesized relationship between circulation and directors' prestige ranking for both the total journal set as well as the research and practitioner subsets. Similarly, no significant relationships occurred between age and directors' prestige rankings. This finding suggests that the directors' collective assessment of a journal's prestige was not based merely on its age, availability, or a wider readership. Table 2 reveals a different pattern for the deans' prestige rankings. Age was significantly correlated with prestige for the total journal set. This relationship became more apparent when analyzed for research and practitioner journal subsets (rho $=.62$ and rho $=.84$, respectively). A probable explanation is that older journals have established reputations, whereas the newer journals may still be shifting for position. In contrast, the deans' ranking was significantly related with circulation only within the practitioner set. One possible interpretation of these findings might be that library educators valued publication in more widely circulated practitioner journals, such as Library Journal, American Libraries, and School Library Journal, because of the service dimension of such writings while publication in more research-oriented journals was valued regardless of the journal's circulation.

TABLE 2

RANK ORDER CORRELATIONS BETWEEN PRESTIGE RANKINGS AND JOURNAL DEMOGRAPHICS FOR THE TOTAL JOURNAL SET AND FOR THE RESEARCH/PRACTITIONER SUBSETS

\begin{tabular}{|c|c|c|c|c|c|c|}
\hline \multirow[b]{2}{*}{ Journal Demographics } & \multicolumn{3}{|c|}{ ARL Prestige Rankings } & \multicolumn{3}{|c|}{ LS Prestige Rankings } \\
\hline & $\begin{array}{c}\text { Total } \\
(\mathrm{N}=28)\end{array}$ & $\begin{array}{l}\text { Research } \\
(\mathrm{N}=17)\end{array}$ & $\begin{array}{l}\text { Practitioner } \\
(\mathrm{N}=11)\end{array}$ & $\begin{array}{c}\text { Total } \\
(\mathrm{N}=28)\end{array}$ & $\begin{array}{l}\text { Research } \\
(\mathrm{N}=17)\end{array}$ & $\begin{array}{l}\text { Practitioner } \\
\text { (N - 11) }\end{array}$ \\
\hline Age & .28 & .37 & .28 & $.41^{\star}$ & $.62+$ & $.84 \dagger$ \\
\hline & .20 & .39 & .0 & .18 & .25 & $.56^{\star}$ \\
\hline Index coverage & $.60 t$ & $.55^{\star}$ & .47 & $.56 t$ & $.50^{*}$ & $.71 t$ \\
\hline Journal orientation & .21 & & $\ldots$ & $.56 t$ & $\ldots$ & $\ldots$ \\
\hline
\end{tabular}

* $\mathrm{p} \leq .05$, one-tail test

$+\mathrm{p} \leq .01$, one-tail test

$\ddagger$ Phi coefficients are reported for orientation-prestige relationships 
Finally, results reported in table 2 confirm the hypothesized relationship between index coverage and journal prestige, with one exception. Directors' collective prestige ranking was not significantly related with index coverage for practitioner journals. Also worth noting is the relatively higher correlation between the deans' ranking and the index coverage of practitioner journals (rho $=.71)$ compared to that for research journals $(\mathrm{rho}=.50)$. These findings are consistent with an overall pattern displayed by table 2: namely, that directors' rankings of research journals and deans' rankings of practitioner journals may more readily be accounted for by journal age, circulation or index coverage than the opposite pairing.

To interpret this correctly, the author needed to understand what age, circulation, and index coverage represent: scholarliness, popularity, or both. Spearman correlations among these three factors confirmed the expected: older journals circulated more frequently and were covered by more indexing services. After defining scholarliness by the references per paper measure and popularity by the popularity and consumption measures, rank order correlations based on the total journal set revealed no significant relationship between scholarliness and any of the three journal "demographics." In contrast, significant relationships existed between age and the two popularity measures (rho $=.41$ and rho $=.46$ ) as well as index coverage and the two popularity measures $(\mathrm{rho}=.58$ and rho $=.59)$. Particularly interesting were the high correlations between index coverage and the popularity measures within the practitioner set (rho $=.93$ and rho $=.92$ ). It would appear that the journal demographics represent popularity and consumption somewhat more than scholarliness. A plausible interpretation of table 2, therefore, might be that deans valued publication in practitioner journals because of their popularity and consumption while something beyond this shaped their rankings of research journals. In the case of the directors, it ap- pears that rankings were generally formed independent of a journal's popularity or consumption. If such a bias existed for directors, it seems to have been directed towards research journals.

\section{Hypothesis Set 2}

To test the second set of hypotheses, Spearman rank-order correlations were computed between the prestige- and citation-based rankings for the total journal set as well as two subsets. These are italicized for each measure in table 3 .

As hypothesized, both deans and directors assigned higher rankings to those journals receiving more direct citations. Total discipline citation counts were significantly correlated with prestige rankings, regardless of journal orientation. As table 3 indicates, the strength of this relationship seems more consistent across journal type for directors than for deans. Values of rho ranged from .65 to .71 for directors and from .54 to .71 for deans. The highest value for the deans occurred for the practitioner subset. It is interesting to see what occurs when examining the relationship between the size-adjusted impact factor and prestige rankings. While the relationship between prestige and discipline impact factor was similarly significant across journal types for directors, it appears to be strongest among research journals. For the deans, the impact factor was significantly correlated with prestige for the research journals (rho = $.60)$. Once corrected for size and, by extension, popularity, the relationship between citation frequency (e.g., impact factor) and deans' prestige ranking disappeared for the practitioner journals. This appears consistent with earlier findings that total citation counts tend to be biased towards large journals.

As demonstrated by table 3, findings did not support the hypothesized relationship between a journal's immediacy index ranking and the deans' prestige ranking for any of the journal groupings. The directors, however, did value more highly those journals with a higher immediacy index (rho $=.41$ ). This was especially true among practitioner jour- 
nals $($ rho $=.63)$. Similarly, only for the directors did the relationship between prestige and a journal's Price's Index even approach significance $(\mathrm{rho}=.55, \mathrm{p}$ $=.081$, practitioner set; rho $=.45, \mathrm{p}=$ .068 , research set). Together these findings indicate that there was a tendency for directors to value more highly those journals reporting recent developments and being quickly cited by current writers in the field.

The overall absence of a significant relationship between Price's Index and the prestige rankings is not surprising given the bimodal distribution of citation age reported for the LIS field. Susan Bonzi's study of LIS citing behavior found mate-

There was a tendency for directors to value more highly those journals reporting recent developments and being quickly cited by current writers in the field.

TABLE 3

RANK ORDER CORRELATIONS BETWEEN PRESTIGE AND DISCIPLINE CITATION MEASURES WITH AND WITHOUT CONTROLLING FOR JOURNAL AGE, CIRCULATION, INDEX COVERAGE, AND ORIENTATION

\begin{tabular}{|c|c|c|c|c|c|c|}
\hline \multirow[b]{2}{*}{$\begin{array}{l}\text { Discipline Measures/ } \\
\text { Controls }\end{array}$} & \multicolumn{3}{|c|}{ ARL Prestige Rankings } & \multicolumn{3}{|c|}{ LS Prestige Rankings } \\
\hline & $\begin{array}{c}\begin{array}{c}\text { Total } \\
(\mathrm{N}=28)\end{array} \\
\left(\begin{array}{l} \\
\end{array}\right.\end{array}$ & $\begin{array}{l}\text { Research } \\
(\mathrm{N}=17)\end{array}$ & $\begin{array}{l}\text { Practitioner } \\
(\mathrm{N}=11)\end{array}$ & $\begin{array}{c}\text { Total } \\
(\mathrm{N}=28)\end{array}$ & $\begin{array}{l}\text { Research } \\
(\mathrm{N}=17)\end{array}$ & $\begin{array}{c}\text { Practitioner } \\
(\mathrm{N}=11)\end{array}$ \\
\hline \multirow{3}{*}{$\begin{array}{l}\text { Total Citations } \\
\text { Age } \\
\text { Circulation } \\
\text { Index }\end{array}$} & $.71+$ & $.68 t$ & $.65^{\star}$ & $.57 t$ & $.54^{\star}$ & $.71^{\star}$ \\
\hline & $.70 t$ & & $.74 t$ & $.60 t$ & & \\
\hline & $.64 t$ & & $.82 t$ & & & \\
\hline \multirow{2}{*}{$\begin{array}{l}\text { Impact Factor } \\
\text { Age }\end{array}$} & $.70 t$ & $.78 t$ & $.67^{\star}$ & $.50 t$ & $.60^{\star}$ & .46 \\
\hline & $.71 t$ & $.74 t$ & $.77 t$ & $.53 t$ & $.63 t$ & \\
\hline $\begin{array}{l}\text { Circulation } \\
\text { Index }\end{array}$ & $.72 t$ & $.79+$ & & $.51 t$ & & \\
\hline \multirow{2}{*}{$\begin{array}{l}\text { Immediacy Index } \\
\text { Age } \\
\text { Circulation } \\
\text { Index }\end{array}$} & $\begin{array}{l}.59 t \\
.41^{*}\end{array}$ & $\begin{array}{l}.71+ \\
.31\end{array}$ & $.63^{\star}$ & .34 & .38 & .31 \\
\hline & & & $\begin{array}{l}.82 t \\
.72 t\end{array}$ & & & \\
\hline \multirow{3}{*}{$\begin{array}{l}\text { Price's Index } \\
\text { Age } \\
\text { Circulation } \\
\text { Index }\end{array}$} & .21 & .45 & .55 & -.17 & .14 & .12 \\
\hline & & & & & & \\
\hline & & & & & & \\
\hline \multirow{3}{*}{$\begin{array}{l}\text { References per Paper } \\
\text { Age } \\
\text { Circulation } \\
\text { Index }\end{array}$} & .22 & .02 & .04 & $.48^{\star}$ & .10 & .02 \\
\hline & & & & $.56 t$ & & \\
\hline & & & & $.57 t$ & & \\
\hline \multirow{3}{*}{$\begin{array}{l}\text { Self-citation Rate } \\
\text { Age } \\
\text { Circulation } \\
\text { Index }\end{array}$} & $-.53^{\star}$ & -.46 & -.28 & $-.52 t$ & $-.58^{\star}$ & -.30 \\
\hline & $-.50 t$ & & & $-.52 t$ & $-.65 t$ & \\
\hline & $-.48 t$ & & & $-.53 t$ & $-.62 t$ & \\
\hline \multirow{3}{*}{$\begin{array}{l}\text { Citation Factor } \\
\text { Age } \\
\text { Circulation } \\
\text { Index }\end{array}$} & .19 & .33 & .23 & .20 & $.56^{\star}$ & $.64^{*}$ \\
\hline & & & & & & \\
\hline & & & & & & \\
\hline \multirow{3}{*}{$\begin{array}{l}\text { Popularity Facto } \\
\text { Age } \\
\text { Circulation } \\
\text { Index }\end{array}$} & .35 & .26 & .41 & .33 & $.51^{\star}$ & .56 \\
\hline & & & & & & \\
\hline & & & & & & \\
\hline \multirow{4}{*}{$\begin{array}{l}\text { Consumption Factor } \\
\text { Age } \\
\text { Circulation } \\
\text { Index }\end{array}$} & .30 & .33 & .52 & .30 & $.61 t$ & $.74 t$ \\
\hline & & & & & & \\
\hline & & & & & & \\
\hline & & & & & & \\
\hline
\end{tabular}

* $\mathrm{p} \leq .05$, two-tail test

$+\mathrm{p} \leq .01$, two-tail test 
rials less than five years old and materials more than fifteen years old were cited most frequently. ${ }^{28}$ The research-oriented journals, in the present study, had a lower average Price's Index than the practitioner-oriented journals (.47 vs. .59). Given the mix of practitionerresearch journals in the top twelve prestige journals and the lower, rather than higher, index values for the research journals, this author believes that Price's Index may be an inappropriate measure of journal quality within a professional field.

Price's Index may be an inappropriate measure of journal quality within a professional field.

As expected, the deans' prestige ranking was significantly related to a journal's average number of references per paper $($ rho $=.48)$, while this was not the case for the directors' ranking. Because journal orientation was based on the number of references per paper, the low correlations within journal subgroups were also anticipated.

Earlier in this paper, it was noted that journals with higher self-citation rates tend to be more highly specialized within sub-fields of a discipline. This seems to be the case for LIS journals as well. Journals such as Law Library Journal, School Library Media Quarterly, Journal of Library History, Philosophy \& Comparative Librarianship, and Reference Services Review had self-citation rates of .50 or higher. As reported in table 3 , the prestige rankings of both directors and deans were inversely correlated with self-citation rates for all journals combined (rho $=-.53$ and rho $=-.52$, respectively). This finding also applied to the deans' assessment of research journals. Journals with higher self-citation rates tended to receive fewer citations from the LIS journal network and ranked lower on the discipline consumption factor. Consequently, this au- thor concludes that, generally speaking, both directors and deans valued publication in journals which hold more central positions in the information flow of the journal network.

The final set of relationships concerns journal popularity as measured by discipline popularity factor, citation factor, and consumption factor. For these three measures, the data failed to support the hypothesized relationships with the directors' prestige rankings, consistent with the pattern revealed earlier in table 2 . When the relationships were analyzed separately for the research and practitioner subsets, the deans assigned significantly higher prestige rankings to those research and practitioner journals having higher citation factors (rho $=.56$ and rho $=.64$, respectively). Practitioner journals with higher citation factors, such as School Library Journal, American Libraries, Library Journal, and Wilson Library Bulletin, tend to feed information to the LIS journal network. The same applies to research journals such as Journal of Education for Library and Information Science, Library Quarterly, College \& Research Libraries, and the Journal of the American Society for Information Science. The rank order correlation between the deans' prestige ranking and the discipline popularity factor was significant only for the research journals. In contrast, the data supported the hypothesized relationship between deans' prestige ranking and the consumption factor for both the research and practitioner sets (rho $=.61$ and rho $=.74$, respectively). Practitioner journals with higher discipline consumption factors, such as Wilson $\mathrm{Li}$ brary Bulletin, American Libraries, and Library Journal, did receive somewhat higher prestige rankings from the deans. This confirmed the already reported research which suggested that the consumption factor better identifies older journals with higher circulation rates and fewer references per paper. The consumption factor may function differently, however, when used to rank research journals. The research journals with higher consumption factors and higher deans' prestige rankings, such as 
Library Quarterly, Journal of the American Society for Information Science, and College $\mathcal{E}$ Research Libraries, were older journals but tended to have more references per article and represented a wider range of circulation rates.

\section{Hypothesis Set 3}

In order to test the last set of hypotheses, regression analysis was used to remove the effect of each journal's demographic factor from the nine citation measures and the Kohl and Davis prestige ratings. The three variables-age, circulation, and index coverage-were normalized through a logarithmic transformation prior to the regression analysis. Spearman rank order correlations were then computed on the remaining residual scores. Because of the number of tests performed, alpha level was set at the .01 level. To emphasize more clearly any patterns which may exist, table 3 reports only significant relationships under each citation measure. The following discussion emphasizes these patterns; the reader interested in actual correlation values is referred to table 3 .

Given the previously determined finding that journal age, circulation, and index coverage correlate significantly with journal popularity and consumption, the results reported in table 3 are not surprising. When controlling individually for age, circulation, and index coverage, the relationship between total citations and deans' prestige rankings all but disappeared. This confirms the biased nature of total citations often attributed to age, size, and frequency of circulation. Controlling for circulation did not eliminate the previously reported relationship for the total journal set because of the low correlation between circulation and deans' prestige ranking reported earlier in table 2 . In contrast, the directors' prestige rankings continued to correspond to citation count rankings, even after removing the effect of age, circulation, and index coverage. As table 3 demonstrates, this relationship held for the total journal set but less clearly for the journal subsets.

Removing the effect of age, circula- tion, and index coverage did not alter the overall relationship between either prestige ranking or the impact factor for the total journal set. Because impact factor already adjusts the size bias present in total citation counts, this was as expected. When the relationships within subgroups were considered, four of the six correlations between prestige and impact factor continued to be significant for the research journals while only one was significant for the practitioner journals. A different pattern occurred for the immediacy-prestige relationships when controlling for the three demographics. The relationship previously reported between the directors' ranking and the immediacy index disappeared for the total journal set but appeared to be even stronger for the practitioner journals. Similarly, even after controlling for age, circulation, and index coverage, the deans' prestige ranking continued to be correlated with the scholarliness measure of references per paper.

Both directors and deans valued publication in journals which hold more central positions in the information flow of the journal network.

Controlling for the three demographics did not alter the nonsignificant relationships previously reported for Price's Index. Also, the significant relationships between the deans' prestige rankings and the three popularity type measures-citation factor, popularity, and consumption-disappeared when controlling for the three factors. These findings are consistent with the fact that age, circulation, and index coverage were also shown to be related to popularity and consumption.

Finally, table 3 indicates that controlling for the demographics did not significantly alter the inverse relationships between prestige rankings and self-citation rate. The directors' ranking 
continued to be significantly related to self-citation rate for the total journal set and the deans' ranking significantly related for the total set as well as the research subset.

\section{CONCLUSIONS}

As stated earlier, this study attempted to gain a better understanding of subjective journal rankings within the LIS field. The purpose was not to challenge the ranking of specific journals, nor to provide current rankings for LIS journals. Rather, an attempt was made to answer the following questions about a specific set of journal rankings. Were these subjective rankings consistent with those derived by more objective, citation-based measures; were these rankings biased by perhaps less scholarly factors such as journal age, circulation, or popularity; and if such relationships existed, were they consistent across journal types and journal raters?

\section{Discipline citation measures identified a core of top journals which overlapped well with the core listings of directors and deans.}

This study tested three sets of hypotheses. Some general patterns emerged.

1. Collectively, the discipline citation measures identified a core of top journals which overlapped well with the core listings of the directors and deans for a similar time period. This consistency between the citing behavior of contributors and the LIS journal literature suggests that the prestige rankings did represent norms for the LIS field at the time of the study.

2. In 1982, library school deans and ARL directors valued publication in journals which fed information to the network and had an impact on current writing in the field. Library school deans specifically valued publication in journals with a research orientation as re- flected by a higher number of references per paper and in older practitioner journals with higher consumption values. ARL directors valued a mix of researchpractitioner journals, but specifically valued research journals which tended to be cited, on the average, more heavily than other journals and practitioner journals which tended to be cited, on the average, more quickly than other journals.

3. Library school deans and ARL directors appeared to use different criteria in judging the value of a publication for tenure and promotion. Scholarliness, as defined by references per paper, and journal consumption were correlates for deans but not directors. Timeliness of information emerged as a factor for directors but not deans.

Beyond these general patterns, study findings support the need to consider research and practitioner journals separately when analyzing knowledge structures in a professional field. For example, the journal consumption factor appeared to be somewhat more appropriate for identifying quality practitioner-oriented journals; the discipline impact factor for identifying quality research journals; and the discipline immediacy index for identifying quality practitioner journals. In addition, this study has offered an approach for developing discipline versions of citation measures for journals not currently covered by available citation indexes and has presented data for an initial assessment of the construct validity of such measures. Discipline versions of total citation count and popularity-consumption-citation factors, for the most part, functioned as anticipated. Each measure was related to uncorrected ratings of prestige, but failed to be related once the biases of age, circulation, or index coverage had been removed. The sizeadjusted discipline impact factor also functioned as expected for research journals, being correlated with prestige even after the effects of journal demographics were removed.

Given the small sample size in this study, especially within orientation 
groups, additional research on an expanded journal network is needed to confirm these patterns, to determine the stability of the prestige rankings and de- tected relationships over time, and to provide further testing of the discipline citation measure approach.

\section{REFERENCES AND NOTES}

1. David F. Kohl and Charles H. Davis, "Ratings of Journals by ARL Library Directors and Deans of Library and Information Science Schools," College \& Research Libraries 46:40-47 (Jan. 1985).

2. Ralph A. Weisheit and Robert M. Regoli, "Ranking Journals," Scholarly Publishing 15:323 (July 1984).

3. William E. McGrath, "Ratings and Rankings: Multiple Comparisons of Mean Ratings," College \& Research Libraries 48:169-73 (Mar. 1987).

4. Paul Metz, "A Statistical Profile of College \& Research Libraries," College \& Research Libraries 50:42 (Jan. 1989).

5. Weisheit and Regoli, "Ranking Journals," p.317.

6. Kohl and Davis, "Ratings of Journals," p.47.

7. R. Todorov and W. Glanzel, "Journal Citation Measures: A Concise Review," Journal of Information Science 14:47-56 (1988).

8. Robert B. Archibald and David H. Finifter, "Biases in Citations-based Ranking of Journals," Scholarly Publishing 18:32 (Jan. 1987).

9. Derek J. De Solla Price, Little Science, Big Science . . . and Beyond 18:132 (New York: Columbia University Pr., 1989), p.161-79.

10. Sydney J. Pierce, "Characteristics of Professional Knowledge Structures: Some Theoretical Implications of Citation Studies," Library and Information Science Research 9:157 (July/Sept. 1987).

11. V. I. Yanovsky, "Citation Analysis Significance of Scientific Journals," Scientometrics 3:223-33 (May 1981).

12. Louis V. Xhignesse and Charles E. Osgood, "Bibliographical Citation Characteristics of the Psychological Journal Network in 1950 and in 1960," American Psychologist 22:778-91 (1967).

13. Todorov and Glanzel, "Journal Citation Measures," p.52.

14. J. C. Smart and C. F. Elton, "Consumption Factor Scores of Psychology Journals: Scientometric Properties and Qualitative Implications," Scientometrics 4:349-60 (Sept. 1982).

15. Graeme Hirst, "Discipline Impact Factors: A Method for Determining Core Journal Lists," Journal of the American Society for Information Science 29:171-72 (July 1978).

16. Alan Singleton, "Journal Ranking and Selection: A Review in Physics," Journal of Documentation 32:258-89 (Dec. 1976).

17. Bruce C. Bennion and Sunee Karschamroon, "Multivariate Regression Models for Estimating Journal Usefulness in Physics," Journal of Documentation 40:217-27 (Sept. 1984).

18. Michael D. Gordon, "Citation Ranking versus Subjective Evaluation in the Determination of Journal Hierarchies in the Social Sciences," Journal of the American Society for Information Science 33:55-57 (Jan. 1982); M. J. White and K. G. White, "Citation Analysis of Psychology Journals," American Psychologist 32:301-5 (1977); T. Roche and D. L. Smith, "Frequency of Citations as a Criterion for the Rankings of Departments, Journals, and Individuals," Sociological Inquiry 48:49-57 (1978); C. C. McDonough, "The Relative Quality of Economics Journals Revisited," Quarterly Review of Economics and Business 15:91-97 (1975).

19. John C. Smart, "Perceived Quality and Citation Rates of Education Journals," Research in Higher Education 19:175-82 (1983).

20. Pierce, "Characteristics," p.163.

21. Gordon, "Citation Ranking," p.57.

22. Smart and Elton, "Consumption Factor Scores," p.358.

23. S. M. Dhawan, S. K. Phull, and S. P. Jain, "Selection of Scientific Journals: A Model," Journal of Documentation 36:24-41 (Mar. 1980). 
24. Patrick Doreian, "Measuring the Relative Standing of Disciplinary Journals," Information Processing \& Management 24:45-56 (1988).

25. Journals are referred to by the titles in use during the study period, 1983-84.

26. Refereeing policy was defined by consensus using the following sources: Daniel O'Connor and Phyllis Van Orden, "Getting into Print," College \& Research Libraries 39:389-96 (Sept. 1978); Norman Stevens and Nora Stevens, eds., Author's Guide to Journals in Library and Information Science (New York: Haworth Pr., 1982); Mary Ann Bowan, comp., Library and Information Science Journals and Serials (Westport, Conn.: Greenwood Pr., 1985); and John Budd, "Publication in Library \& Information Science: The State of the Literature," Library Journal 113:125-31 (Sept. 1, 1988).

27. For reasons of consistency the author used the term prestige ranking throughout most of this study. The reader is reminded that Kohl and Davis collected ratings of journals which were then used to rank order the journals.

28. Susan Bonzi, "Characteristics of a Literature as Predictors of Relatedness Between Cited and Citing Works," Journal of the American Society for Information Science 33:213 (July 1982).

\section{APPENDIX A. DISCIPLINE JOURNALS ANALYZED}

Journals from Kohl and Davis Study

American Libraries $[$ AmLib] $(\mathrm{P})$

Collection Management [CollMgt] (R)

College \& Research Libraries [CRL] (R)

Drexel Library Quarterly [DLQ] (R)

Information Processing \& Management [IP$\mathcal{E} M G T](R)$

Information Technology \& Libraries [IT\&L] (R)

International Library Review [ILibRev] (R)

Journal of Academic Librarianship [JAL] (R)

Journal of Education for Librarianship [JEL] (R)

Journal of Information and Image Management

[JIIM] (P) [formerly Journal of Micrographics;

Micrographics Today]

Journal of Library History, Philosophy \& Comparative Librarianship $[J L H]$ (R)

Journal of the American Society for Information Science [JASIS] (R)

Law Library Journal [LawL]] (P)

Library Acquisitions: Practice \& Theory [LibAcq] (P)

Library Journal $[L]](\mathrm{P})$

Library Quarterly [LQ] (R)

Library \& Information Science Research [LISR] (R)

Library Resources \& Technical Services [LRTS] (R)

Library Trends [ $\mathrm{LibTr}](\mathbf{R})$

Microform Review $[$ MicroR] (P)

Online [Online] $(\mathrm{P})$

Public Libraries [PubLib] (P)

Reference Services Review [RSR] (P)

$R Q(\mathrm{R})$

School Library Journal [SL]] (P)
School Library Media Quarterly [SLMQ] (R)

Special Libraries [SpLib] (R)

Wilson Library Bulletin $[$ WLB] $(\mathrm{P})$

Additional LIS Journals

The American Archivist

Aslib Proceedings

Bulletin of the Medical Library Association

Behavioral \& Social Sciences Librarian

Canadian Library Journal

Collection Building

Database

Government Publications Review

IFLA Journal

International Classification

International Forum on Information and Documentation

Journal of Documentation

Journal of Information Science

Journal of Librarianship

Journal of Library Administration

Libri

Online Review

Program

Resource Sharing \& Information Networks

Scholarly Publishing

Scientometrics

The Serials Librarian

Technical Services Quarterly

Top of the News

$(R)$ indicates a research orientation; $(P)$ indicates a popular, practitioner orientation.

\section{APPENDIX B. DEFINITIONS OF CITATION MEASURES}

Unless stated otherwise, citation counts mentioned in each of the following definitions are tallies of initial journal references appearing in the major source items in 1983-84 issues of the fiftytwo LIS journal set: 
1. Total discipline citations [TDC]: total citations received by a journal,

2. Discipline impact factor [DIF]: total citations received by source items appearing in 1981-1984 issues of a journal divided by the total number of source items appearing in 1981-83 issues of that journal,

3. Discipline immediacy index [DII]: total citations received by 1983 and 1984 source items of a journal from discipline journals published in the same year, divided by the total number of source items appearing in 1983-84 issues of that journal,

4. References per paper [RP]: number of references appearing in 1983-84 source items of a journal divided by the number of $1983-84$ source items,

5. Price's Index [PI]: the proportion of total references in 1983-84 source items of a journal given to works published in the preceding five years (ie., 1979-1983 and 1980-1984),

6. Discipline citation factor [DCF]: total citations received by a journal, divided by the number of references given by that journal in 1983-84,

7. Discipline popularity factor [DPF]: total number of LIS journals citing a journal in 1983-84 divided by the total number of LIS journals referenced by a journal in 1983-84,

8. Discipline consumption factor [DCSF]: the product of the discipline citation factor and the discipline popularity factor, and

9. Discipline self-citation rate [DSCR]: the proportion of citations received which are selfcitations.

\section{IN FORTHCOMING ISSUES OF \\ COLLEGE \& RESEARCH LIBRARIES}

Automation in College Libraries

by Richard Hume Werking

Designing Library Instruction for Undergraduates

by Delia Neuman

The Changing Domain of Subject Access

by Prudence W. Dalrymple and Jennifer A. Younger

Role Identity of Women Academic Librarians

by Pamela J. Cravey

Scientific Journal Prices

by Kenneth E. Marks, Steven P. Nielsen, Craig H. Peterson, and Peter E.

Wagner 